\title{
Habitat Classification of Cilo Glaciers and Their Surroundings
}

\author{
İbrahim DEMIRR ${ }^{\mathrm{a}, *}$ (D), Murat ÜNALb (D) \\ a Bitlis Eren University, Faculty of Arts and Sciences, Department of Biology, 1300, Bitlis, Turkey \\ b Van Yüzüncü Yll University, Faculty of Education, Department of Biology Education, Zeve Campus, Tuşba-Van, Turkey
}

\section{ART I C L E IN F O}

\section{Article history:}

Received 12 October 2021

Received in revised form 01 November 2021

Accepted 08 November 2021

\section{Keywords: \\ EUNIS \\ Cilo Glaciers \\ Hakkari}

Habitat mapping

\begin{abstract}
A B S T R A C T
This study was carried out for the habitat classification of the Cilo glaciers and their environments, which have significant biological diversity within the borders of Hakkari National Park and are under serious threat especially due to global climate change in Turkey. The study material consists of the data obtained as a result of field studies conducted in 2018-2019. As a result of the studies, 11 habitat types were determined on the area according to habitat types of The European Nature Information System (EUNIS) and observations about these habitats were given. In addition, 4 types of vegetation are determined according to the plant density with satellite images of the area. This research reveals the importance of habitat type determination studies for important nature areas.
\end{abstract}

(C) 2020. Turkish Journal Park Academic. All rights reserved.

\section{Introduction}

The human population is expected to reach 9 billion by 2050. In this case, it is predicted that $10-20 \%$ of natural areas will be replaced by agriculture and urban infrastructure, further reducing the habitat of wildlife. (Martinuzzi et al., 2015). Anthropogenic pressures affect the structure of local ecological communities and may lead to local extinction of species. This could lead to reduced ecosystem functionality (Tilman et al., 2001; Cardinale et al., 2006) and global extinction (Vié et al., 2009). increased human population and consumption will likely result in further habitat loss (Newbold et al., 2014; Krausmann et al., 2013). On the other hand, the pressure of global climate change on sensitive habitats is a major threat to sensitive species living in these areas (Kromp-Kolb and Formayer, 2005; Dow and Downing, 2006). Natural areas are particularly vulnerable to climate change due to their limited adaptive capacity, and some of these systems may suffer significant and irreversible damage. (Omann et al., 2009).

Due to increasing environmental problems, the loss of Biodiversity is expected to continue to increase in the coming years. The most effective way to prevent or reduce the loss of biodiversity is to preserve the habitat. Therefore, identifying and identifying habitats with unique characteristics is extremely important (Geven 2016; Schamberger and Krohn 1982; Schroeder, 1986; Çakmak and Aytaç, 2020; Süel et al., 2018).

Conservation of natural areas requires comprehensive classification systems of natural habitat types. They are essential for creating protected area networks, conducting natural area surveys, setting monitoring targets, management planning, environmental impact assessments and ecological restoration (Chytrý et al., 2020; McDermid, Chytrý et al., 2015). Conservation programs can tackle the main cause of extinction by reducing the loss of natural habitats and the species they host (Eken et al., 2014; Bruner et al., 2001).

Despite the fact that the number of EUNIS studies in Turkey has increased in recent years, it is small when compared to Europe. Priority might be given to locations with potentially significant biological and habitat diversity, such as national parks, nature reserves, and special environmental protection zones, in the following process of identifying the areas to be investigated on habitat categorization. Because these areas differ from their immediate surroundings in terms of ecology, climate, and

\footnotetext{
* Corresponding author. Tel.: +0 434222 0020; fax: +0 4342229143

E-mail address: idemir@beu.edu.tr

ORCID : 0000-0003-1533-556X (i. Demir), 0000-0002-6224-8269 (M. Ünal)
} 
topography. In this situation, it will affect the floristic composition and hence the habitat type, allowing new habitat types to be identified in these regions (Çakmak, 2017; Çakmak and Aytaç, 2021).

The Cilo Mountains and Sat Glacier Lakes, located inside the boundaries of Hakkari province in Turkey's Eastern Anatolian region, are one of the sites with priority protection. The area, which was recently declared a National Park, is also among the Important Natural Areas that host many species with its unique endemics. This area is the habitat of Cephalaria hakkarica, Cirsium hakkariacum and many other locally endemic plant and other species (Eken et al., 2006). However, human and climate change pressures on the area have taken their toll in recent years. Determining the habitat types of this area, which is very important in terms of biodiversity, is extremely important for the management and sustainability of the area. The EUNIS habitat classification (European Union Nature Information System), developed by the European Environment Agency, has been used in nature conservation as a tool to identify habitat units during monitoring and assessments. (Černecký et al., 2020; Moss, 2008).

Habitat maps for sensitive areas can help achieve national biodiversity conservation goals and assess conservation status (Bilasi et al., 2000).

The aim of this research is to determine habitat types according to EUNIS habitat classification for the protection of endangered species with increasing anthropogenic pressures and global climate change threat in recent years. Thus, to ensure the formation of data for the protection of the rich biodiversity in this area and to form the basis for management plans.

\section{Material and Methods}

\subsection{Study area}

The area is $87.6 \%$ covered with mountainous areas and there are many mountains and peaks above $3000 \mathrm{~m}$ altitude. Uludoruk (Reşko) Hill (4135 m) on the Cilo Mountains is also the second highest point in Turkey after Mount Ağrl. Cilo Glacier Mountain is located in the eastern part of the Southeast Taurus Mountain (Fig. 1). It's also known as the most glaciated region of Turkey (Yavaşli and Ölgen, 2008).

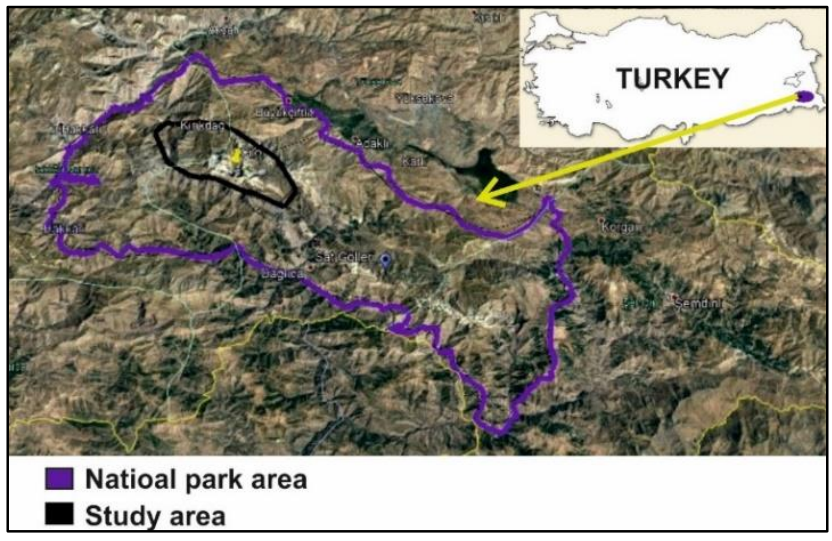

Figure 1. Location map of the study area

\subsection{Field work}

Flora studies were carried out in the research area in 2018-2019. The samples obtained as a result of these studies were recorded and identified. In addition, habitat types in the area and plant species on these habitats were determined.

\subsection{Maps Usage}

\subsubsection{Vegetation map}

First of all, the Normalized Difference Vegetation Index (NDVI) method, which is frequently preferred in mapping the distribution areas of plants, was used to create the vegetation map of the study area (Rouse et al., 1974). SENTINEL 2A satellite images with a spatial resolution of $10 \mathrm{~m}$ were used to create the vegetation map. Images were obtained by downloading cloudless images (25.06.2020) from "https://coda.eumetsat.int/\#/home". In the study, Band 8 (NIR) and Band 4 (Red) were used in the images consisting of 13 bands. Vegetation maps were created using the SNAP program with the formula given below.

$$
N D V I=\frac{\text { Band } 8-\text { Band } 4}{\text { Band } 8+\text { Band } 4}
$$

In the vegetation map obtained; areas devoid of vegetation, covered with weak vegetation, medium and dense vegetation were determined (Fig. 2).

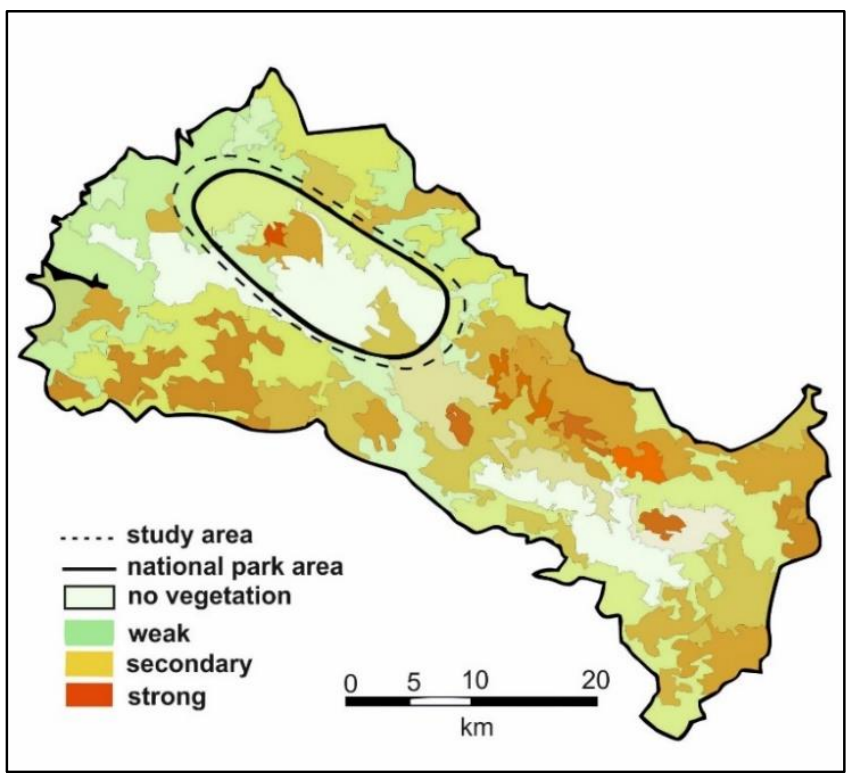

Figure 2. Vegetation map of Study area

\subsubsection{Habitat types map}

According to the EUNIS Habitat types (https://eunis.eea.europa.eu/habitats-code-

browser.jsp?expand=\#level_G), the findings obtained as a result of the field studies were mapped. First of all, the polygon map of the area was drawn and habitats were placed on these polygons. These habitats were created according to the following codes of EUNIS and each colored with a different color (Fig. 5) 
C: Inland surface waters

D: Mires, bogs and fens

E: Grasslands and lands dominated by forbs, mosses or lichens

$\mathrm{H}$ : Inland unvegetated or sparsely vegetated habitats

\section{Results and discussion}

11 habitat types have been identified in the area according to the coding of EUNIS. These; C (C1.7, C2.2), D (D4.2), E (E1.2E), H (H2.2; H3.61; H3.62; H4.1; H4.23; H5.22; H5.36), These habitats consist of steppe, high mountain meadow formations, areas that are weak in terms of vegetation and completely devoid of vegetation. Habitat maps are used as a basis for management plans and to define preservation objectives at the regional and national levels by ecologists, environmentalists, administrators, and nature conservationists (Mergen and Karacaoğlu 2015; Moss, 2008). The habitats identified on the area are as follows.

\section{C1.7: Permanent lake ice}

Covers a small area east of the Cennet Cehennem valley. There are no plants in this habitat type (Fig3).

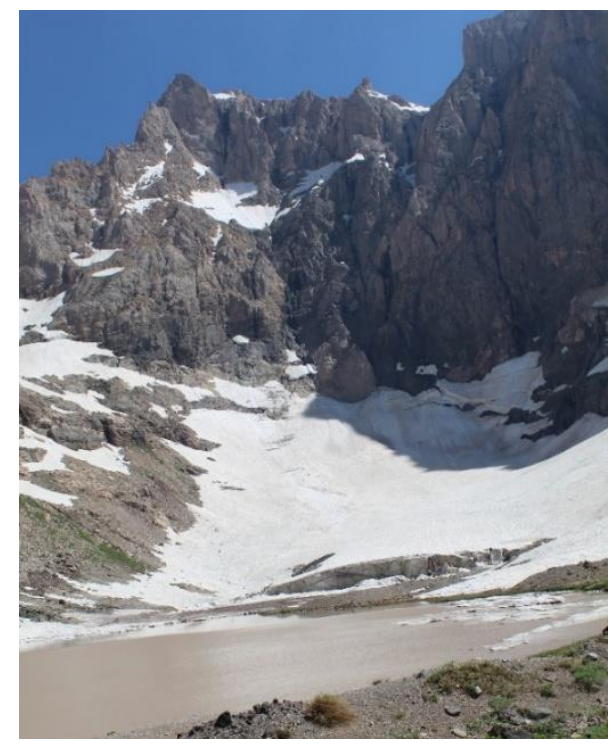

Figure 3. Cilo glacial lake

Permanent or almost permanent lake ice formations that produce continuous ice sheets that cover the whole surface all year or recede to a section of the lake during the summer, and are accompanied or replaced by floating ice blocks, rafts, and hummocks. On a local, seasonal, or permanent basis, they can extend to the lake's whole depth. They can be found at high latitudes and high altitudes (https://eunis.eea.europa.eu/habitatscode-browser.jsp?expand=\#level_G).

\section{C2.2: Permanent non-tidal, fast, turbulent watercourses}

They are the streams starting from the glacial lake and continuing along the Cennet Cehennem valley. It is called Dêz Stream by the local people and it was named that way in the Flora of Turkey (Davis, 1965-1985). The source of these streams is Cilo glaciers and snow patches. The flow rate and amount of the creeks fed by small rivers increase as you go down. The power plant established near Kırıkdağ village was built on this stream.

\section{D4.2: Basic mountain flushes and streamsides, with a rich arctic-montane flora}

These are areas where the ground water is high and the temperature is low, around the Cilo glacial lake and along the Dez stream. The dominant species in this area vary according to the vegetation period. But Poa pratensis L., Ranunculus poluninii P.H.Davis, Primula auriculata Lam.,Tabl., Colchicum kurdicum (Bornm.) Stef., Puschkinia scilloides Adams are the most prominent species on the area. Apart from this, the habitat is the habitat of locally endemic plants such as Myosotis platyphylla Boiss, Primula davisii W.W.Sm.

\section{E1.2E: Irano-Anatolian steppes}

This habitat type covers most of the area. Cennet Cehennem Valley, which is especially rich in vegetation and biodiversity, is one of the important areas of this habitat type. Although the dominant species vary, the dominant species in this area are the Tragagantic steppes formed by the spiny Astragalus sp. species (Figure 4). Apart from this, it is represented by other hemicryptophyte and gametophyte form species in the area. Along with the spiny Camephyte Astragalus species, genus such as Thymus, Verbascum, Eryngium, Helichyrsum, Cousinia, Ferula, Centaurea, Allium, Dianthus, Artemisia, Achillea, Salvia are abundant. While the most dominant genus in the Gramine group are Poa, Elymus, Bromus species in the area, the most intense species is Psathyrostachys fragilis. Some of the important endemics in this habitat type in the area are Astragalus latistipulatus D.F. Chamb., Astragalus sachanewii Sirj., Astragalus yueksekovae V. Matthews, Gypsophila adenophylla Barkoudah, Gypsophila baytopiorum Kit Tan, Gypsophila hakkiarica Kit Tan, Cousinia satdagensis Hub.-Mor., Cousinia hakkarica Hub.-Mor. and Crocus kotschyanus K.Koch

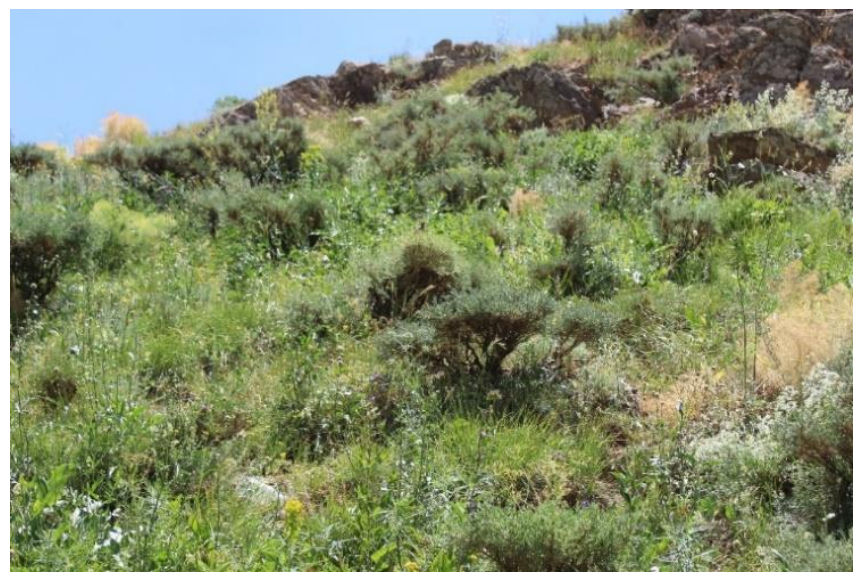

Figure 4. A view from the steppes in the area

\section{H2.2: Cold limestone screes}

This habitat type is the formations formed by the fragmentation 
of the rocky slopes, especially around Kırıkdağ village and the eastern parts of the Cennet Cehennem Valley, over time. Soil accumulation is low in this habitat. Factors such as so little soil, water scarcity, rock mobility that flows downstream hindering vegetative growth, only host special species that can adapt to the environment. For these reasons, the vegetation is very weak. In these areas, there are species such as Melica ciliate L, Capparis spinosa L.

\section{H3.61 - Bare weathered rock and outcrop habitats}

Consists of bare rocky areas with less plant species than H3.62. Although very few plants are seen in these areas, it is the habitat of local endemics such as Rosularia davisii Muirhead, Scrophularia pumilio Lall

\section{H3.62: Sparsely vegetated weathered rock and outcrop habitats}

It consists of steep cliffs forming mountain peaks from Kırıkdağ Village towards the Cennet Cehennem valley. The highest point of the area is Reşko Hill ( $4135 \mathrm{~m}$ ). This habitat type is one of the important habitats in terms of biodiversity, although the vegetation is weak. These rocks constitute the habitat of important locally endemic species such as Silene araratica subsp. davisii (Chowdhuri) Ghaz, Silene cartilaginea Hub.-Mor., Silene lucida Chowdhuri, Rosularia davisii Muirhead, Draba thylacocarpa (Nábelek) Hedge and Theodorovia karakuschensis (Grossh.) Kolak.

\section{H4.1: Snow packs}

The surroundings and northern slopes of the Cilo glacial lake are in this habitat type. This area is devoid of vegetation. There are some bulbous species (Puschkinia scilloides Adams, Colchicum kurdicum (Bornm.) Stef. etc) only at the bottom of the melting snowpacks.

\section{H4.23: Glaciers}

Although glaciers are devoid of vegetation, they play an important role in the biodiversity of the area. According to Yavaşlı and Ölgen (2008) there are 5 glacier areas on the area. These are: Erinç (Suppa Durak) Glacier, x Valley glaciers (Mia Hvara or Avaspi) and Uludoruk (Gelyaşin or İzbırak) glaciers. (Figure 2).

\section{H5.22: Sparsely vegetated glacial moraines}

It is one of the habitat types that occupy the least space in the area. Vegetation is very sparse

\section{H5.36: Shallow rocky soils with very sparse or no vegetation}

This habitat type is located in the lower part of the Cilo glaciers and margins of the Dez Stream. Soil is very low, so there is either a complete deficiency of vegetation or very sparse vegetation.

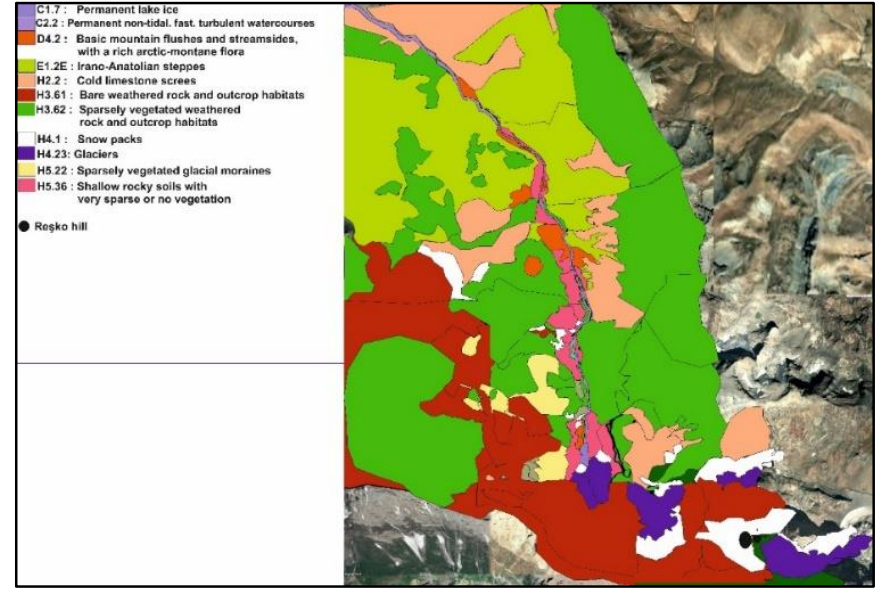

Figure 5. The EUNIS habitat map of the study area.

\section{Acknowledgement}

Some of the data presented in this study were obtained within the scope of Hakkari Province Biodiversity Inventory and Monitoring Project of Republic of Turkey Ministry of Agriculture and Forestry General Directorate of Nature Conservation and National Parks. In addition, satellite images of the vegetation map of the region were prepared by Dr. Mustafa Akkuş (Van Yüzüncü Yıl University). We would like to take this opportunity to thank the aforementioned institution and person.

\section{References}

Abdulhasan, N. 2009. Habitat mapping project of the proposed Iraqi Marshlands National Park area. BioRisk, 3, 55.

Blasi, C., Carranza, M.L., Frondoni, R., and Rosati, L. 2000. Ecosystem classification and mapping: A proposal for Italian Landscapes. Applied Vegetation Science, 3, 233-242. doi:10.2307/1479002

Bruner, AG., Gullison, RE., Rice, RE., and da Fonseca, GAB. 2001. Effectiveness of parks in protecting tropical biodiversity. Science 291, 125-128.

Çakmak, M. H., and Aytaç, Z. 2021. EUNIS Habitat Sınıflandırmasının Türkiye Durum Değerlendirmesi. Bilge International Journal of Science and Technology Research, 5(2), 111-117.

Çakmak, M.H. 2017. Avrupa Doğa Bilgi Sistemi (EUNIS) Habitat Sınıflandırması ve Soğuksu Milli Parkı Pilot Alanında Uygulanması (Uzmanlık Tezi). T. C. Orman ve Su İşleri Bakanlığı, Ankara, Türkiye

Çakmak, M.H., and Aytaç, Z. 2020. Determination and mapping of EUNIS habitat types of Mamak District (Ankara), Turkey. Acta Biologica Turcica, 33(4), 227-236.

Cardinale, BJ., Srivastava, DS., Duffy, JE., Wright, JP., Downing, AL. Sankaran, M., and Jouseau, C. 2006 Effects of biodiversity on the functioning of trophic groups and ecosystems. Nature 443, 989-992. (doi:10. 1038/nature05202)

Černecký, J., Gajdoš, P., Špulerová, J., Halada, L., Mederly, P., Ulrych, L., ... and Rybanič, R. 2020. Ecosystems in Slovakia. Journal of Maps, 16(2), 28-35.

Chytrý, M., Tichý, L., Hennekens, S. M., Knollová, I., Janssen, J. A., Rodwell, J. S., ... and Schaminée, J.H. 2020. EUNIS Habitat Classification: Expert 
system, characteristic species combinations and distribution maps of European habitats. Applied Vegetation Science, 23(4), 648-675.

Davis, P.H. (Eds) 1965-1985. Flora of Turkey and the East Aegean Islands, Vol 1-9. Edinburgh University, Edinburgh

Eken, G., Bennun, L., Brooks, T. M., Darwall, W., Fishpool, L. D., Foster, M., ... and Tordoff, A. 2004. Key biodiversity areas as site conservation targets. BioScience, 54(12), 1110-1118.

Eken, G., Bozdoğan, M., İsfendiyaroğlu, S., Kılıç, D. T., and Lise, Y. 2006. Türkiye'nin Önemli Doğa Alanları. Doğa Derneği, Ankara, 2, 348-351

European environment agency. (September, 2021,). EUNIS habitat type hierarchical view. https://eunis.eea.europa.eu/habitats-codebrowser.jsp?expand=\#level_G

Geven, F., Ozdeniz, E., Kurt, L., Bolukbasi, A., Ozbey, B. G., Ozcan, A. U., and Turan, U. 2016. Habitat Classification and Evaluation of the KöyceğizDalyan Special Protected Area (Muğla/Turkey). Rendiconti Lincei, 27(3), 509-519.

Krausmann, F., Erb, K-H., Gingrich, S., Haberl H, Bondeau A, Gaube V, Lauk C, Plutzar C, and Searchinger. TD. 2013 Global human appropriation of net primary production doubled in the 20th century. Proc. Natl Acad. Sci. USA 110, $10 \quad 324-10329$. (doi:10.1073/pnas.1211349110)

Kromp-Kolb, and H., Formayer, H. 2005. Schwarzbuch Klimawandel. Wie viel Zeit bleibt unsnoch?. Ecowin Verlag der Top Akademie GmbH,

Martinuzzi, S., Withey, J. C., Pidgeon, A. M., Plantinga, A. J., McKerrow, A. J., Williams, S. G., ... and Radeloff, V. C. 2015. Future land-use scenarios and the loss of wildlife habitats in the southeastern United States. Ecological Applications, 25(1), 160-171.

McDermid, G. J., Franklin, S. E., and LeDrew, E.F. 2005. Remote sensing for large-area habitat mapping. Progress in Physical Geography, 29(4), 449-474.

Mergen, O., and Karacaoğlu, C. 2015. Tuz Lake Special Environment Protection Area, Central Anatolia, Turkey: The EUNIS Habitat Classification and Habitat Change Detection between 1987 and 2007. Ekoloji Dergisi, 24, 95.

Moss, D. 2008. EUNIS Habitat Classification - a Guide for Users. European Topic Centre on Biological Diversity, Paris.
Moss, D. 2008. EUNIS habitat classification. European topic centre on biological diversity. 27 pp. Retrieved from http:// citeseerx.ist.psu.edu/viewdoc/download?doi=10.1.1.231. 4607\&rep=rep1\&type=pdf

Newbold, T., Hudson, L. N., Phillips, H. R., Hill, S. L., Contu, S., Lysenko, I., ... and Purvis, A. 2014. A global model of the response of tropical and sub-tropical forest biodiversity to anthropogenic pressures. Proceedings of the Royal Society B: Biological Sciences, 281(1792), 20141371.

Omann, I., Stocker, A., and Jäger, J. 2009. Climate change as a threat to biodiversity: An application of the DPSIR approach. Ecological Economics, 69(1), 24-31.

Rouse, J.W., Haas, R.H., Schell, J.A., and Deering, D.W. 1974. Monitoring vegetation systems in the Great Plains with ERTS. NASA special publication, 351(1974), 309.

Salzburg, Dow, K., and Downing, T.E., 2006. The Atlas of Climate Change. Earthscan

Schamberger, M, and Krohn, WB. 1982. Status of the habitat evaluation procedures. Trans N Amer. Wildl. Nat Resour Gmf 47,154-164

Schroeder, RL. 1986. Habitat suitability index models: wildlife species richness in shelter belts. US Fish and Wildlife Service Biological Report 82,10-128

Süel, H., Şentürk Ö., Mert A., Özdemir S., and Yalçınkaya B. 2018. Habitat Suitability Modeling and Mapping. V. International Multidisciplinary Congress of Eurasia Proceedings July 24-26, 2018, Barcelona, Spain, 536-549.

Tilman, D., Reich, PB., Knops, J., Wedin, D., Mielke, T., and Lehman, C. 2001 Diversity and productivity in along-term grassland experiment. Science 294, 843-845. (doi:10.1126/science.1060391)

Vie', J-C., Hilton-Taylor, C, and Stuart SN. 2009 Wildlife in a changing world: an analysis of the 2008. Red Listof Threatened Species. Gland, Switzerland: IUCN.

Yavaşl, D.D., and Ölgen, M.K. 2008. Assessing the variation of recent glaciers in Buzul (Cilo) mountain with remote sensing and meteorological data. In International Conference on Geographic Information Systems (ICGIS) (pp. 2-5). 